\title{
The studies on the preparation of instant noodles from wheat flour supplementing with sweet potato flour
}

\author{
M. L. J. Taneya*, M. M. H. Biswas and M. Shams-Ud-Din \\ Department of Food Technology and Rural Industries, Bangladesh Agricultural University, Mymensingh-2202, \\ Bangladesh, *E-mail: taneyabau@yahoo.com
}

\begin{abstract}
The study reports on the effect of composite flours consisting of wheat and sweet potato flour on the physicochemical and sensory properties of instant noodles. Sweet potato flour was incorporated into wheat flour at flour replacement levels of $0,10,20$ and $30 \%$. The levels of sweet potato flours increased in the formulations of instant noodle that increased ash, starch, crude fiber and total carbohydrate contents but decreased level of protein. The instant noodles with $20 \%$ sweet potato flour had decreased moisture content but had higher levels of fat and calories (per $100 \mathrm{~g}$ ) when compared with $10 \%$ sweet potato flour in the formulation. The instant noodles with $0,10,20$ and $30 \%$ of sweet potato flours that higher level of water absorption and increased volume of cooked noodles. Instant noodles with $30 \%$ sweet potato flour that the highest sensory scores for colour, flavour, texture and overall acceptability when compared with control and other samples but noodles with $20 \%$ sweet potato flour was equally acceptable. Studies on the shelf life of dried instant noodles packed in polyethylene bags showed no remarkable change in mold growth, texture and flavor but free fatty acid value, peroxide value and moisture content slightly increased gradually after 90 days duration at room temperature.
\end{abstract}

Keywords: Instant noodles, Sweet potato flours, Shelf life etc.

\section{Introduction}

Noodles are long thin piece of food made from a mixture of flour, water and eggs usually cooked in soup or boiling water. An instant noodle is a food item made from unleavened dough that is made from different types of ingredients. The Instant noodles are dried or precooked noodles fused with oil and sold with a packet of flavoring and is consumed among the people of all socioeconomic levels both urban and rural areas of the country. It appeared to have originated in Japan in the 1950s and today, is produced in over 80 countries worldwide (Parvez, 2009). The Instant noodles are important for its low cost and acceptable flavor. It also be noted that, after dried and fried of instant noodles, it's contain good source of nutrition like carbohydrate and fat.

Sweet potato (Ipomoea batatas) is an important starch rich tuber crop which is available throughout the country. Sweet potato flour is less expensive, nutritious, and ordinarily harmless source of carbohydrates, calories. $100 \mathrm{~g}$ flesh of sweet potato contains $7 \mathrm{IU}$ vitamins $\mathrm{A}$ which are about one and half times more than daily requirement of Vitamin $\mathrm{A}$ for an adult.

(Winarno, 1982). Sweet potato is low in protein content, its lysine content (an essential amino acid limiting in cereals) is higher than that of rice; hence when taken in combination with rice, it improves the amino acid spectrum and hence the biological value of the diet.

To reduce pressure on rice and change food habits it is a vital issue to conduct research involving the use of non-rice commodity for production of convenient food products. Formulation of breads, biscuits, cakes, noodles etc. could be developed using sweet potato flour mixed with wheat flour. This sweet potato-wheat flour blend could be a valuable raw material to substitute for rice. The country produces about 3,07,221 metric tons of sweet potato in year 2007-08 (BBS,2008). A substantial amount of potato is spoiled and wasted due to inadequate cold storage facilities and insufficient post harvest handling. It is alarming that post harvest loss of sweet potato when valued in monetary term, reflects a tremendous loss in economy in the country. Minimization of post harvest losses of sweet potato through proper handling and processing into value-added products is thus warranted in order to help attain food security at least to some extent in the country. 
Processing of sweet potato flour into value added product like noodles have potential to increase income and improve livelihood of sweet potato growers. However, these are not suitable for direct adoption in Bangladesh due to socio-economic and cultural limitation. Further, due to least commercial intervention, the sweet potato is still to be brought into different value added food products for commercial use. With the above views in consideration, this study has been undertaken to achieve the following objectives: (a) to evaluate the storage stability of the mixed flour consisting sweet potato and wheat flour and (b) to evaluate the quality of instant noodles using sweet potato and wheat flour.

\section{Materials and Methods}

The study was conducted in laboratory of the Departmental of Food Technology and Rural Industries, Bangladesh Agricultural University, Mymensingh.

\section{Materials}

Wheat flour, sweet potato and other major ingredients were procured from the local market.

Methods for preparation of Flours: Wheat flour was collected from local market. Sweet Potatoes collected from local market were washed, peeled, trimmed, sliced and blanched for 5 minute in boiling water. Then dried in a cabinet dryer at $60-65^{\circ} \mathrm{C}$ for $8-10$ hours and finally ground to produce sweet potato flour.

\section{Basic formulation of instant noodle}

The basic formulation for preparation of instant noodles from composite flour is presented in Table: 1. Four types of sample had significant difference in wheat flour, sweet Potato flour and water. The wheat flour content decreased gradually $100 \mathrm{~g}, 90 \mathrm{~g}, 80 \mathrm{~g}$ and $70 \mathrm{~g}$ in the Sample $\mathrm{C}, \mathrm{S}_{1}, \mathrm{~S}_{2}, \mathrm{~S}_{3}$ respectively. The sweet Potato flour increased gradually $0 \mathrm{~g}, 10 \mathrm{~g}, 20 \mathrm{~g}$ and $30 \mathrm{~g}$ in the Sample $\mathrm{C}, \mathrm{S}_{1}, \mathrm{~S}_{2}, \mathrm{~S}_{3}$ respectively. The water increased gradually $31 \mathrm{ml}, 32 \mathrm{ml}, 33 \mathrm{ml}$ and $34 \mathrm{ml}$ in the Sample $C, S_{1}, S_{2}, S_{3}$ respectively. Other ingredients were same in all sample.

Table 1. Basic formulation of composite flour instant noodles

\begin{tabular}{|l|l|c|c|c|c|}
\hline SI & \multicolumn{1}{|c|}{ Ingredients } & \multicolumn{3}{c|}{ Samples } \\
\cline { 3 - 5 } No. & & $\mathrm{C}$ & $\mathrm{S}_{1}$ & $\mathrm{~S}_{2}$ & $\mathrm{~S}_{3}$ \\
\hline 1. & Wheat flour $(\mathrm{g})$ & 100 & 90 & 80 & 70 \\
\hline 2. & Sweet Potato flour $(\mathrm{g})$ & 0 & 10 & 20 & 30 \\
\hline 3. & Onion powder $(\mathrm{g})$ & 0.5 & 0.5 & 0.5 & 0.5 \\
\hline 4. & Water $(\mathrm{ml})$ & 31 & 32 & 33 & 34 \\
\hline 5. & Sodium bicarbonate $\left(\mathrm{NaHCO}_{3}\right)(\mathrm{g})$ & 1 & 1 & 1 & 1 \\
\hline 6. & Salt $(\mathrm{g})$ & 1 & 1 & 1 & 1 \\
\hline 7. & Starch $(\mathrm{g})$ & 2 & 2 & 2 & 2 \\
\hline 8. & Citric acid $(\mathrm{g})$ & 0.1 & 0.1 & 0.1 & 0.1 \\
\hline 9. & Zinger juice $(\mathrm{ml})$ & 1 & 1 & 1 & 1 \\
\hline 10. & Oil $(\mathrm{ml})$ & 5 & 5 & 5 & 5 \\
\hline 11. & Egg $(\mathrm{ml})$ & 10 & 10 & 10 & 10 \\
\hline 12. & Garlic powder $(\mathrm{g})$ & 0.1 & 0.1 & 0.1 & 0.1 \\
\hline 13. & Cumin Powder $(\mathrm{g})$ & 0.5 & 0.5 & 0.5 & 0.5 \\
\hline
\end{tabular}

$C=$ control noodles with wheat flour only; $S_{1}=$ instant noodles with $90 \%$ wheat flour, $10 \%$ sweet potato flour; $S_{2}=$ instant noodles with $80 \%$ wheat flour, $20 \%$ sweet potato flour and $S_{3}=$ instant noodles with $70 \%$ wheat flour, $30 \%$ sweet potato flour. 


\section{Procedures for preparation of instant noodles}

All the ingredients such as wheat flour, sweet potato flour, $\mathrm{NaHCO}_{3}$, salt, starch, citric acid, zinger juice, oil, onion, cumin and garlic powder, egg (fresh) were weighed as shown in Table 1. The composite flour mixed with warm water and kneaded for 10 minute to prepare dough. The dough was transferred to a vertical noodles making machine and longer types of noodles were made. The prepared raw noodles were then steamed at $100^{\circ} \mathrm{C}$ for 3 minutes. The noodles were then dried in a cabinet dryer at $68^{\circ} \mathrm{C}$ for 2 hours. The cooled and dried instant noodles were packed in polythene bags of $100 \mathrm{~g}$ instant noodles.

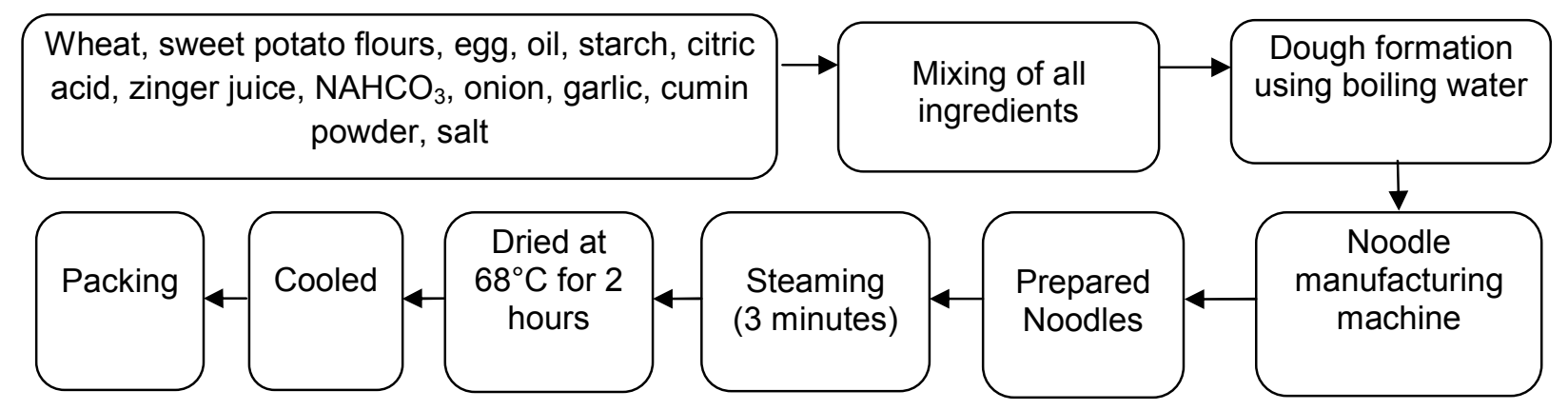

Fig.1. Flow chart of instant noodles

\section{Chemical analysis}

The wheat and sweet potato flours and the prepared instant noodles were analyzed for moisture, protein, fat, ash, crude fiber, starch content, peroxide value, free fatty acid value by AOAC (2004) method. The total carbohydrates were calculated by approximation i.e. by subtracting the measured protein, moisture, fat and ash from 100 (Srivastava \& Sanjeev, 2002).

$\%$ Moisture $=\frac{\text { Loss in weight }}{\text { Weight of sample }} \times 100$

$\%$ Ash $=\frac{\text { Weight of residue }}{\text { Weight of sample }} \times 100$

$\%$ Nitrogen $=\frac{\left(T_{s}-T_{b}\right) \times N \text { of acid } \times \text { meq. of } N_{2}}{\text { Weight of sample }(g m)} \times 100$

where,

$\mathrm{T}_{\mathrm{s}}=$ Titre volume of the sample $(\mathrm{ml})$

$\mathrm{T}_{\mathrm{b}}=$ Titre volume of the blank $(\mathrm{ml})$

Meq. of $\mathrm{N}_{2}=0.014$

Therefore,

$\%$ Protein $=\%$ Nitrogen $\times 6.25$

$\%$ Reducing Sugar $=\frac{F \times D \times 100}{T \times W \times 100}$

Where, $\mathrm{F}=$ Fehling's Factor, $\mathrm{D}=$ Dilution, $\mathrm{T}=$ Titre, $\mathrm{W}=$ Weight of sample

$\%$ Non-reducing sugar $=\%$ Invert sugar $-\%$ Reducing sugar

$\%$ Total sugar $=\%$ Reducing sugar $+\%$ Non-reducing sugar 
$\%$ Crude fat $=\frac{\text { Weight of fat }- \text { soluble material }}{\text { Weight of sample }} \times 100$

$\%$ starch $=\%$ Reducing sugar $\times 0.90$

$\%$ wet gluten $=$ weight of wet gluten $\times 100$

$\%$ of dry gluten $=$ weight of dry gluten $\times 100$

Calories $=[9 \times(\mathrm{g}$ fat $)]+4 \times(\mathrm{g}$ protein $)+4 \times(\mathrm{g}$ carbohydrate $)$

Peroxide value (mili equ.or millimoles) $=\frac{\text { Sample titre }- \text { Blank titre }}{\text { Weight of sample taken }} \times \mathrm{N}$. of $\mathrm{Na}_{2} \mathrm{~S}_{2} \mathrm{O}_{3} \times 1000$

Free fatty acid value $=\frac{\text { Titre value } \times \mathrm{N} . \text { of } \mathrm{NaOH} \times 56.1}{\text { Weight of sample taken }}$

\section{Sensory Evaluation}

The consumer's acceptability of developed instant noodles taste was evaluated by a testing panel. The hedonic rating test was used to determine the acceptability. The panelists were chosen from different social status. The panelists rated their acceptability of the product on a 01-09 point hedonic scale.

\section{Storage Study}

Volume and water absorption were measured according to Hummel (1966). The stored instant noodles were analyzed at $0,30,60,90$ days. During storage the change in moisture content, peroxide and free fatty acid value, texture, flavor, mold growth was investigated.

\section{Results and Discussion}

\section{Composition of wheat and sweet potato flour}

The wheat and sweet potato flour were analyzed for moister, protein, fat, ash, total carbohydrate, crude fiber and gluten. The results are presented in Table 2.

Table 2. Composition of wheat and sweet potato flour

\begin{tabular}{|l|c|c|}
\hline \multicolumn{1}{|c|}{ Components } & Wheat flour & Sweet potato flour \\
\hline Moisture (\%) & 13.20 & 9.32 \\
\hline Protein (\%) & 11.07 & 3.3 \\
\hline Fat (\%) & 0.90 & 1.32 \\
\hline Ash (\%) & 0.6 & 2.72 \\
\hline $\begin{array}{l}\text { Total carbohydrate } \\
(\%, \text { by difference) }\end{array}$ & 74.23 & 83.34 \\
\hline Crude fiber (\%) & & \\
\hline Dry gluten (\%) & 0.40 & 1.9 \\
\hline Wet gluten (\%) & 12.26 & - \\
\hline Total sugar (\%) & 25.52 & - \\
\hline
\end{tabular}

As shown in Table 2, the wheat flour contained moisture $13.20 \%$, protein $11.07 \%$, fat $0.90 \%$, ash $0.6 \%$, total carbohydrate (by difference) $74.23 \%$, crude fiber $0.4 \%$ and dry gluten $12.26 \%$. Horald et al. (1981) reported that the wheat flour contains moisture $13.5 \%$, protein $8-13 \%$, fat $0.9-1.4 \%$, carbohydrate $65-$ $75 \%$, fiber $0.1-0.3 \%$ and ash $0.3-0.5 \%$. Matj (1960) also reported that the wheat flour contains protein $7.5-$ $15.0 \%$, fat $1.0-1.5 \%$, ash $0.3-1.0 \%$, fiber $0.4-0.5 \%$, carbohydrates $68-76 \%$. The findings of this study are more or less in agreement with these values. The minor variations might be due to the varietal difference, seed quality, agro-ecological condition, fertilizer use, extent of drying, storage condition, methods of analyses etc. 
The sweet potato flour contained moisture $9.32 \%$, protein $3.3 \%$, fat $1.32 \%$, ash $2.72 \%$, total carbohydrate (\% by difference) $83.34 \%$ and crude fiber 1.9\% (Table 2). Talburt and Smith (1967) reported the composition of sweet potato flour as moisture $7.5 \%$, ash $1.94 \%$, protein $5.13 \%$, fat $0.85 \%$, crude fiber $1.63 \%$. The reported data are quite similar to that of the present study.

The wet gluten of wheat flour used was $25.52 \%$ and dry gluten was $12.26 \%$ (Table 2). Hummel (1966) reported that semolina from North African wheat will contain as an average just about $20 \%$ of wet gluten and from good American Amber Durum will contain more than $11 \%$ of dry gluten.

\section{Composition of instant noodles}

The four different samples of instant noodles C (100\% wheat flour), $S_{1}(90 \%$ wheat flour, $10 \%$ sweet potato flour), $S_{2}\left(80 \%\right.$ wheat flour, $20 \%$ sweet potato flour) and $S_{3}(70 \%$ wheat flour, $30 \%$ sweet potato flour) were analyzed for moisture, protein, fat, ash, starch, crude fiber, total carbohydrate, calories and the results are presented in Table.3.

Table 3. Composition of prepared instant noodles

\begin{tabular}{|c|c|c|c|c|c|c|c|c|}
\hline Samples $^{*}$ & $\begin{array}{c}\text { Moisture } \\
(\%)\end{array}$ & $\begin{array}{c}\text { Ash } \\
(\%)\end{array}$ & Protein (\%) & $\begin{array}{c}\text { Fat } \\
(\%)\end{array}$ & $\begin{array}{c}\text { Starch } \\
(\%)\end{array}$ & $\begin{array}{c}\text { Total } \\
\text { carbohydrate } \\
(\%)\end{array}$ & $\begin{array}{c}\text { Crude fiber } \\
(\%)\end{array}$ & $\begin{array}{c}\text { Calories } \\
(\text { per 100g) }\end{array}$ \\
\hline $\mathrm{C}$ & 8.64 & 2.21 & 12.51 & 6.25 & 56.75 & 70.39 & 0.58 & 387.85 \\
\hline $\mathrm{S}_{1}$ & 7.43 & 2.26 & 12.60 & 5.30 & 57.10 & 72.41 & 0.75 & 387.74 \\
\hline $\mathrm{S}_{2}$ & 6.83 & 2.37 & 11.80 & 5.51 & 58.78 & 73.49 & 0.80 & 390.75 \\
\hline $\mathrm{S}_{3}$ & 6.27 & 2.44 & 11.66 & 5.75 & 59.80 & 73.80 & 0.54 & 393.59 \\
\hline
\end{tabular}

${ }^{*} \mathrm{C}\left(100 \%\right.$ wheat flour), $S_{1}\left(90 \%\right.$ wheat flour, $10 \%$ sweet potato flour), $S_{2}(80 \%$ wheat flour, $20 \%$ sweet potato flour) and $\mathrm{S}_{3}(70 \%$ wheat flour, $30 \%$ sweet potato flour)

\section{Studies on the cooking quality of noodles}

The four different samples of instant noodles $C\left(100 \%\right.$ wheat flour), $S_{1}$ (90\%wheat flour, $10 \%$ sweet potato flour), $S_{2}$ ( $80 \%$ wheat flour, $20 \%$ sweet potato flour) and $S_{3}(70 \%$ wheat flour, $30 \%$ sweet potato flour) were analyzed for volume of $100 \mathrm{~g}$ of dried noodles, cooking time, water absorption, volume of cooked product, increased volume (\%) and cooking quality of instant noodles. The results are presented in Table 4.

Table 4. Cooking quality test of prepared instant noodles

\begin{tabular}{|l|c|c|c|c|c|c|}
\hline Samples $^{*}$ & $\begin{array}{c}\text { Volume of } 100 \mathrm{~g} \\
\text { of dried instant } \\
\text { noodles }(\mathrm{ml})\end{array}$ & $\begin{array}{c}\text { Cooking } \\
\text { time }(\mathrm{min})\end{array}$ & $\begin{array}{c}\text { Water } \\
\text { absorption } \\
(\mathrm{g})\end{array}$ & $\begin{array}{c}\text { Volume of } \\
\text { cooked instant } \\
\text { noodles }(\mathrm{ml})\end{array}$ & $\begin{array}{c}\text { Increase } \\
\text { volume } \\
(\%)\end{array}$ & $\begin{array}{c}\text { Cooking } \\
\text { quality }\end{array}$ \\
\hline $\mathrm{C}$ & 130 & 3 & 125 & 200 & 53.84 & Very Good \\
\hline $\mathrm{S}_{1}$ & 150 & 2 & 129 & 215 & 43.33 & Very good \\
\hline $\mathrm{S}_{2}$ & 160 & 2 & 135 & 225 & 40.62 & Very good \\
\hline $\mathrm{S}_{3}$ & 160 & 2 & 143 & 235 & 46.87 & Very good \\
\hline
\end{tabular}

${ }^{*} \mathrm{C}\left(100 \%\right.$ wheat flour), $\mathrm{S}_{1}\left(90 \%\right.$ wheat flour, $10 \%$ sweet potato flour), $\mathrm{S}_{2}$ (80\% wheat flour, $20 \%$ sweet potato flour) and $\mathrm{S}_{3}(70 \%$ wheat flour, $30 \%$ sweet potato flour)

\section{Cooking time and volume of prepared noodles}

Instant noodles for evaluation of quality in this study were cooked to the optimum time of each individual sample. Determination of optimum cooking time were achieved by using method similar to that described by Oh et al. (1983) where $10 \mathrm{~g}$ of instant noodles were boiled in $1000 \mathrm{~mL}$ of boiling tap water and after each minute of cooking for the first 2 minutes, noddles were removed and squeezed between clear glass slides. This procedure was then repeated by removing the noodle severy 15 seconds until the white core disappeared. This point is the optimum cooking time. 
As shown in Table 4, the lowest cooking time was $2 \mathrm{~min}$ for the sample $\mathrm{S}_{1}, \mathrm{~S}_{2}$ and $\mathrm{S}_{3}$. The cooking time required for sample $C$ was $3 \mathrm{~min}$. The percent increase volume of the cooked product for sample $C$ was $53.84 \mathrm{ml}$, for $S_{1}$ was $43.33 \mathrm{ml}$, for $S_{2}$ was $40.62 \mathrm{ml}$ and for $S_{3}$ was $46.87 \mathrm{ml}$. The volume of cooked product increased from $130 \mathrm{ml}$ to $200 \mathrm{ml}$ for sample C, $150 \mathrm{ml}$ to $215 \mathrm{ml}$ for $\mathrm{S}_{1}, 160 \mathrm{ml}$ to $225 \mathrm{ml}$ for $\mathrm{S}_{2}$ and $160 \mathrm{ml}$ to $235 \mathrm{ml}$ for $S_{3} S_{3}$ had value higher than twice. Cooking quality was also studied by Kent (1990) that after boiling in water for $10 \mathrm{~min}$, the macaroni should swell to twice its original volume. Medvedev et al. (1984) reported in his experiment that on final product quality pasta dough mixed at increased temperature in the range of $50-80^{\circ} \mathrm{C}$, increase in temperature improved product color (by inactivitiving polyphenoloxidase) gave higher pasta strength and resulted in reduced cooked time and starch gelatinization because of preliminary cooking occurring during dough mixing. Mixing dough at $<70^{\circ} \mathrm{C}$ gave a normal product. According to this characteristic it is observed that all the samples had high quality.

\section{Sensory evaluation of the instant noodles}

The mean scores for colour, flavour, texture and overall acceptability of different instant noodles prepared with different formulations such as $\mathrm{C}, \mathrm{S}_{1}, \mathrm{~S}_{2}$ and $\mathrm{S}_{3}$ are presented in Table 5 . Analysis of variance was carried out for colour, flavour, texture and overall acceptability of the instant noodles and results showed that panelists accepted all the instant noodles with the different degrees of acceptability. The DMRT test further revealed that colour, flavour, texture and overall acceptability of the instant noodle containing $30 \%$ sweet potato flour and $20 \%$ sweet potato flour was equally acceptable and was significantly better than those with $0 \%$ or $10 \%$ sweet potato flour.

Table 5. Mean sensory scores of instant noodles containing wheat and sweet potato flour

\begin{tabular}{|l|c|c|c|c|}
\hline \multirow{2}{*}{ Sample } & \multicolumn{4}{c|}{ Sensory attributes } \\
\cline { 2 - 5 } & Color & Flavor & Texture & Overall acceptability \\
\hline $\mathrm{C}$ & $6.9^{\mathrm{b}}$ & $6.7^{\mathrm{b}}$ & $6.5^{\mathrm{c}}$ & $6.9^{\mathrm{b}}$ \\
\hline $\mathrm{S}_{1}$ & $7.0^{\mathrm{b}}$ & $7.1^{\mathrm{b}}$ & $7.0^{\mathrm{bc}}$ & $7.2^{\mathrm{b}}$ \\
\hline $\mathrm{S}_{2}$ & $7.5^{\mathrm{ab}}$ & $7.3^{\mathrm{ab}}$ & $7.5^{\mathrm{ab}}$ & $7.7^{\mathrm{ab}}$ \\
\hline $\mathrm{S}_{3}$ & $7.7^{\mathrm{a}}$ & $7.8^{\mathrm{a}}$ & $8.0^{\mathrm{a}}$ & $0.1^{\mathrm{a}}$ \\
\hline $\mathrm{LSD}$ value & 0.9519 & 0.8031 & 0.8500 & 0.7989 \\
\hline Coefficient of variation (COV) & $13.86 \%$ & $11.29 \%$ & $12.34 \%$ & $10.56 \%$ \\
\hline Probability & 0.0110 & 0.0052 & 0.0109 & 0.0034 \\
\hline
\end{tabular}

$\mathrm{C}=$ control noodles with $100 \%$ wheat flour; $\mathrm{S}_{1}=90 \%$ wheat flour, $10 \%$ sweet potato flour; $\mathrm{S}_{2}=80 \%$ wheat flour, $20 \%$ sweet potato flour and $\mathrm{S}_{3}=70 \%$ wheat flour, $30 \%$ sweet potato flour.

As shown in Table 5, the increase the \% of sweet potato flour, the acceptability increased within certain range. Increase the sweet potato flour in accordance decrease the wheat flour. As well as decrease the gluten contain that decrease the binding capacity. The DMRT test indicated that the texture of instant noodle containing $30 \%, 20 \%$ and $10 \%$ sweet potato flour were equally acceptable and was significantly better than those with $0 \%$ sweet potato flour.

\section{Colour}

It can be seen from Table 5 that the score for colour of all the noodles samples were higher than that of control noodles (C). The instant noodles containing 30\% sweet potato flour secured the highest score (7.7) for colour and the noodles containing only wheat flour gave lowest score (6.9). The score of colour was 7.0 in sample $S_{1}$ and 7.5 in sample $S_{2}$.

\section{Flavour}

As shown in Table 5, the score for flavour of all the instant noodle samples are higher than that of control noodles. The noodles containing $30 \%$ sweet potato flour gave the highest score for flavour of 7.8 and the noodles containing only wheat flour secured the lowest score (6.7). The score of flavour was 7.1 in sample $S_{1}$ and 7.3 in sample $S_{2}$. 


\section{Texture}

Table 5 shows that the score for texture of all the noodles samples are higher than that of control noodles. The range of instant noodles score for texture was 6.5-8.0. The lowest score (6.5) was secured by noodle containing wheat flour and the score highest score (8.0) for texture gave by instant noodles containing $30 \%$ sweet potato flour. The score of texture was 7.0 in sample $S_{1}$ and 7.5 in sample $S_{2}$.

\section{Overall acceptability}

The highest score of overall acceptability was 8.1 in $S_{3}$ which has no significant difference with sample $S_{2}$ and $S_{1}$. But the sample $C$ is significantly different from the other sample (Table 5) and seemed the lowest score (6.9).

\section{Storage studies of prepared instant noodles}

Samples of each type $(100 \mathrm{~g})$ were packed in polyethylene bags to evaluate the shelf life of the noodles during storage. The shelf life of the processed instant noodles was assessed over a period of 90 days at ambient conditions $\left(32-37^{\circ} \mathrm{C}\right.$ and $\left.79-87 \% \mathrm{RH}\right)$ and the results are presented in Table 6.

\section{Peroxide value (mili.eqv./ kg)}

The peroxide value (mill.eqv. $/ \mathrm{kg}$ ) found from Table 6 , at 0 days the values $C$ was $23.40, S_{1}$ was $25.01, S_{2}$ was 24.14 and S3 was 24.0 and after 90 days the values $C$ was $25.00, S_{\text {, was }} 25.94, S_{2}$ was 24.00 and $\mathrm{S}_{3}$ was 24.13. Holas and Kratochvil (1982) reported that changes of lipids during storage of cereal products were- for 0 days the peroxide value of cereal mixture was 25.7. After 60days it was 14.8 and after 90 days it was found 34.6. Gotoh et al. (2007) reported that the changes in peroxide value (PV) in instant noodles stored at 40 to $60^{\circ} \mathrm{C}$ gradually increased and then rapidly increased after exceeding approximately 30 mequiv $/ \mathrm{kg}$, regardless of the oxidation temperature. This finding indicates that the PV standard value 30 mequiv/ $\mathrm{kg}$ is meaningful for suppressing the oxidation-induced formation of toxic compounds. The reported data satisfy the analysis.

Table 6. Effect of storage on physiochemical properties of mixed flour (wheat, sweet potato) instant noodles

\begin{tabular}{|c|c|c|c|c|c|c|}
\hline \multirow[b]{2}{*}{$\begin{array}{l}\text { Ambient } \\
\text { temperature }\end{array}$} & \multirow{2}{*}{$\begin{array}{c}\text { Period of } \\
\text { storage } \\
\text { (days) }\end{array}$} & \multirow[b]{2}{*}{$\begin{array}{c}\text { Types of instant } \\
\text { noodles }\end{array}$} & \multicolumn{3}{|c|}{ Observations } & \multirow[b]{2}{*}{ Remarks } \\
\hline & & & $\begin{array}{c}\text { Moisture } \\
\text { content (\%) }\end{array}$ & $\begin{array}{c}\text { Peroxide value } \\
\text { (mili eqv./Kg) }\end{array}$ & $\begin{array}{c}\text { Free fatty acid } \\
\text { value }(\%)\end{array}$ & \\
\hline \multirow{16}{*}{$32-37^{\circ} \mathrm{C}$} & \multirow{4}{*}{0} & $\mathrm{C}$ & 8.64 & 23.40 & 1.02 & \multirow{4}{*}{ Very good } \\
\hline & & $\mathrm{S}_{1}$ & 7.43 & 25.01 & 1.04 & \\
\hline & & $\mathrm{S}_{2}$ & 6.83 & 24.14 & 1.03 & \\
\hline & & $\mathrm{S}_{3}$ & 6.27 & 24.00 & 1.01 & \\
\hline & \multirow{4}{*}{30} & C & 8.84 & 24.70 & 1.06 & \multirow{4}{*}{ Very good } \\
\hline & & $S_{1}$ & 7.50 & 25.32 & 1.05 & \\
\hline & & $\mathrm{S}_{2}$ & 6.85 & 23.62 & 1.04 & \\
\hline & & $\mathrm{S}_{3}$ & 6.28 & 23.68 & 1.02 & \\
\hline & \multirow{4}{*}{60} & $\mathrm{C}$ & 8.89 & 24.78 & 1.10 & \multirow{4}{*}{ Very good } \\
\hline & & $\mathrm{S}_{1}$ & 7.51 & 25.38 & 1.09 & \\
\hline & & $\mathrm{S}_{2}$ & 6.86 & 23.63 & 1.08 & \\
\hline & & $\mathrm{S}_{3}$ & 6.28 & 23.72 & 1.08 & \\
\hline & \multirow{4}{*}{90} & $\mathrm{C}$ & 8.90 & 25.00 & 1.20 & \multirow{4}{*}{ Very good } \\
\hline & & $S_{1}$ & 7.52 & 25.94 & 1.13 & \\
\hline & & $\mathrm{S}_{2}$ & 6.87 & 24.00 & 1.11 & \\
\hline & & $\mathrm{S}_{3}$ & 6.29 & 24.13 & 1.10 & \\
\hline
\end{tabular}

No Mold growth; Texture were always Crisp; Flavor were very Good

\section{Free fatty acid value}

The free fatty acid value in 0 days were $1.02 \%$ for sample $C, 1.04 \%$ for $S_{1}, 1.03 \%$ for $S_{2}$ and $1.01 \%$ for $S_{3}$ and in 30 days the values were $1.06 \%$ for sample $C, 1.05 \%$ for $S_{l}, 1.04 \%$ for $S_{2}$ and $1.02 \%$ for $S_{3}$ (Table 6). So, the observed value satisfied the reported value. No remarkable change in free fatty acid value upto 60 days of storage. But upto 90 days of storage, the value increased. Horald et al. (1981) reported that with most oils acidity beings to be noticeable to the palate when the free fatty acid (FFA) calculated as oleic acid is $0.5-1.5 \%$. The analysis satisfies the range that reported. 


\section{Moisture content}

As shown in Table 6 , is found that $32-37^{\circ} \mathrm{C}$ temperature and $79-87 \%-\mathrm{RH}$ the moisture contents were $8.64 \%$ for sample $\mathrm{C}, 7.43 \%$ for $\mathrm{S}_{1}, 6.83 \%$ for $\mathrm{S}_{2}$ and $6.27 \%$ for $\mathrm{S}_{3}$. No remarkable change in moisture content. After 60 days of storage the moisture content slightly increased. After 90 days of storage the moisture content of the prepared sample increased from the initial sample that is $8.90 \%$ for sample C, $7.52 \%$ for $S_{1}, 6.87 \%$ for $S_{2}$ and $6.29 \%$ for $S_{3}$. Hakoda et al. (2006) studied on determination of the moisture content of instant noodles were 1.6-2.6 and 3.9-4.8\% for fried noodles, and 0.3-1.5 and 1.3$2.9 \%$ for nonfried noodles, respectively.

\section{Mould growth}

Mould growth was observed after 15 days interval. No mould growth occurred after storage of 90 days. Jensen et al. (2004) reported that moulds were high in some refrigerated noodles and low in shelf stable noodles. No remarkable change in the texture and flavor of the prepared sample after 90 days of storage. The moisture content also should not exceed $10 \%$.

\section{Conclusion}

This study reports the effects of various levels of sweet potato flour on the quality of instant noodles. Four samples of instant noodles were processed incorporating 0,10, 20 and $30 \%$ sweet potato flour and analyzed for physical, chemical and organoleptic characteristics. On the basis of composition, sensory attributes and shelf-life of the processed noodles, it may be concluded that good quality mixed flour instant noodle may be processed incorporating $30 \%$ sweet potato flour in the formulation of instant noodles. This instant noodle may find widespread by many health conscious people in the society.

\section{References}

AOAC. 2004. Official Method of Analysis. Association of Official Agricultural Chemist. $12^{\text {th }}$ Ed. Washington, D.C., USA.

BBS. 2008. All crops summary. Planning Division, Ministry of planning Govt. Republic of Bangladesh, Dhaka. p. 7.

Gotoh, N., Iwasawa, A., Watanabe, H., Osato, R. and Wada, S. 2007. Oxidation of fats and oils in instant noodles stored under various conditions. Food Lipids. 14(4): 350-365.

Hakoda, A., Kasama, H., Sakaida, K., Suzuki, T. and Yasui, A. 2006. Determination of the moisture content of instant noodles: interlaboratory study. AOAC International. 89(6): 1585-1590.

Holas, J., and Kratochvil, J., 1982. Progress in cereal chemistry and technology, Research Institute of Flour-Milling and Baking Industries, Prague

Horald, E., Ronald, S.K. and Ronald, S. 1981. Pearson's Chemical Analysis of Foods. Churchill Livingstone, Edin Burgh, London Melbournge and New York. p. 155, 535-536.

Hummel, C. 1966. Macaroni Products manufacture, processing and packing. Second edition, Food Trade Press, LTD, London, p. 1, 11, 16, 207.

Jensen, N., Hocking, A.D., Miskelly, D. and Berghofer, L.K. 2004. Microbiological safety of high moisture noodles: Marketplace survey of noodles sold in Australia. Food Sci. Austral., 56: 71-78.

Kent, N.L. 1990. Technology of Cereals. Third edition, Pergamon Press, Oxford, New York, p. 151.

Matj, S.A. 1960. Bakery Technology and Engineering. The Avi Publishers Company, West Port, Connecticut United States of America. p. 12.

Medvedev, G.M., Malandeeva, N.I., Kiseleva, R.F., and Semko, V.T. 1984. Drying of pasta from heat-treated dough. 10: 41-42.

Oh, N. H., Seib, P. A., Deyoe, C. W., \& Ward, A. B. (1983). Noodles. I. Measuring the textural characteristics of cooked noodles. Cereal Chemistry, 60(6), 433-438.

Parvez, S. 2009. Noodles Sales Sizzle. The Daily Star, Date: 25-11-2009. P.1.

Srivastava, R.P. and Sanjeev, K. 2002. Fruit and vegetable preservation principles and practices. Third Revised and Enlarged Edition, International Book Distributing Co. p. 363-364.

Talburt, W.F. and Smith, O. 1967. Potato processing. The Avi Publishing Company. Inc. Printed in the United States of America. p. 236-237, 473 .

Winarno, F.G. 1982. Sweet Potato Processing and by product utilization in the tropics in sweet potato processing of first international symposium, AVRDC, Taiwan, p. 162-171. 